\title{
The True Effects of Winning Wars
}

\author{
Zhuorong Tang
}

Shenzhen Middle School, Shenzhen, China

2055634798@qq.com

\begin{abstract}
This paper aim to explore whether winning wars brings the country and its people better lives or not. This work analyzes the condition of Austerity Britain after World War 2, and generated the conclusion of winning the war actually couldn't bring definite or comprehensive benefits to a country and its people.
\end{abstract}

Keywords: History, war, social effects, social developments

\section{INTRODUCTION}

"In a life and death struggle, we cannot afford to leave our destinies in the hands of failures." This is a statement by British Labor Party Opposition leader Clement Attlee during World War II [1]. Just like him, there were hundred and thousand leaders who had insisted on their willingness to lead their countries to victory during wars.

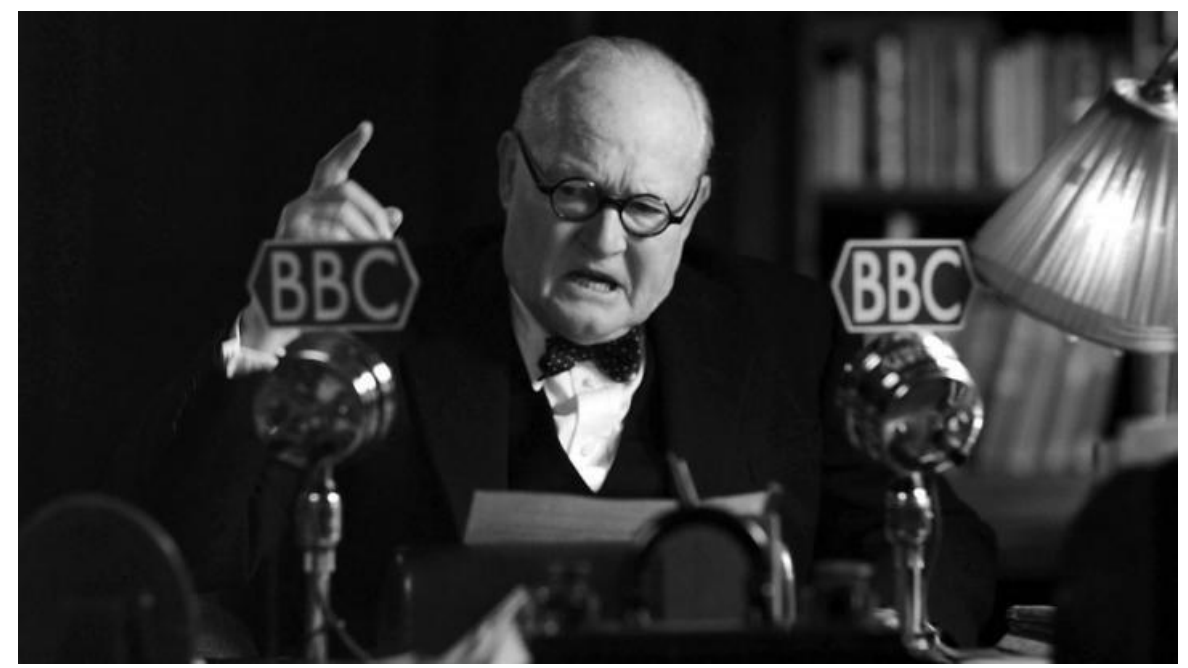

Figure 1 "Churchill: When Britain Said No.” BBC Two, BBC, 24 Apr. 2019, www.bbc.co.uk/programmes/b05x31b6.

Moreover, winning a war was always regarded as an honorable event and better for the whole country and society. People from all walks of life, no matter of their age were eager to win a war rather than to lose one. However, we needed to think deeply as to World War II, as it was one of the most tragic wars in the history. Did winning World War II bring people more benefits or not? To explore and solve this question, I will focus on the catastrophic effects of victory in Great Britain. The suffering of people in postwar Great Britain shows vividly that winning World War II did not benefit them at all.

\section{ANALYSIS AND REFLECTION}

To prove that Great Britain actually did not benefit all the citizens after winning World War II, two aspects would be discussed in my following essay. First of all, secondary sources shall be facilitated to demonstrate the economic situation of postwar Britain. Second, primary sources shall be used to illustrate how the austerity period of postwar Britain having affected its citizens.

Firstly, the economy didn't run as smoothly as Britain had expected. When World War II ended in 1945 after Japan surrendered, Britain had been caught in an extremity. While other countries who had won the War 
were enjoying the harvest of victory, Great Britain was pushed into the age of austerity. According to statistics [2], Great Britain had spent about $\$ 7$ billion, namely more than a quarter of national wealth, on the war. What's worse, by the end of 1945, the debt of Britain had increased from $\$ 760$ million to $\$ 3500$ million, which was over $200 \%$ and almost reaching $250 \%$ of their GDP of that time [3], and the country's gold reserve had decreased from $\$ 1.1$ billion to $\$ 4$ million. In conclusion, these statistics showed that Britain had spent a large proportion of its money and assets on the war, which left the massive amount of debt after that. In other words, the age of austerity was a period when the whole country had a declining economic situation and suffered from money shortage.
However, not only the general situation of postwar Great Britain had become awful as showed statistically, but also the average British citizens had suffered severely as well after the war, as demonstrated by analyzing the following primary sources from that period.

Secondly, life in postwar Britain was "Dreariness everywhere". One schoolteacher wrote in his diary in 1948 "Streets are deserted, lighting is dim, people's clothes are shabby and their tables are bare."[3]. Even though one single paragraph from a teacher living in Great Britain in 1948 couldn't draw any conclusion yet, but we could still get a hint of people' life from it. In fact, people were suffering miserable life then. One of the most obvious features was the shortage of daily necessities.

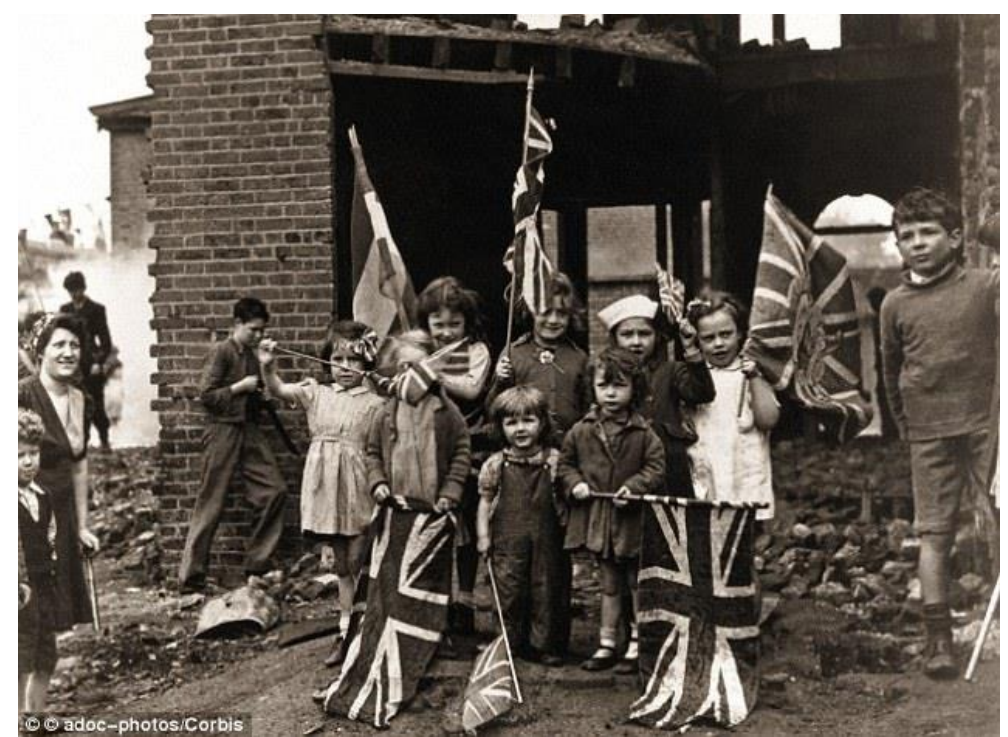

Figure 2 Steve, Humphries. WWII Children Reveal Poverty and Austerity of Post-War Britain. Dailymail.co.uk. Steve Humphries and Sue Elliot, May 11, 2015. https://www.dailymail.co.uk/news/article-3076121/Families-poor-childrenslept-chests-drawers-Austerity-don-t-know-born-haunting-stories-generation-lived-two-world-wars-movinglyreveal.html.

Winston Churchill once warned the British citizens that after World War II, "Britain may be left bankrupt" [4]. Sure enough, a series of social problems followed the war: Transportation was severely damaged due to the destruction by weapons during the war; factories ran out of fuel because they had devoted all the fuels into making weapons; the facilities had been so damaged that people at home did not have enough electricity to cook with, and over a third of the whole country's twelve million houses had no hot water provided [5]. Besides, "Rationing (during the war) was still in force, especially with bread, due to a bad wheat harvest". In addition to this, it was written in the newspaper article published in 1945 that "(people) Bemoan the absence of turkey, plum pudding, port, crackers and crystallized fruits and forget about the absence of sirens, bombs, doodlebugs, rockets, fire watching and all the other nuisances of the past few years
[6]. " This article was published on December 22, 1945, when Christmas was approaching. Christmas meant to be a festive time when people recovered from the loss from war, celebrating the victory and enjoying the postwar peace and harvest. But back then, due to the negative economy situation of the government partly, people were even focusing more on the lack of food and the lack of daily necessities. And even though the war had ended, and all the bombs and weapons had stopped damaging, people's joy to celebrate or live happily had gone nowhere.

Another significant result that the postwar Britain society had presented was the dim and dark social atmosphere. During and after World War II it was a period when the crime rate in Great Brain had rose dramatically [7]. 


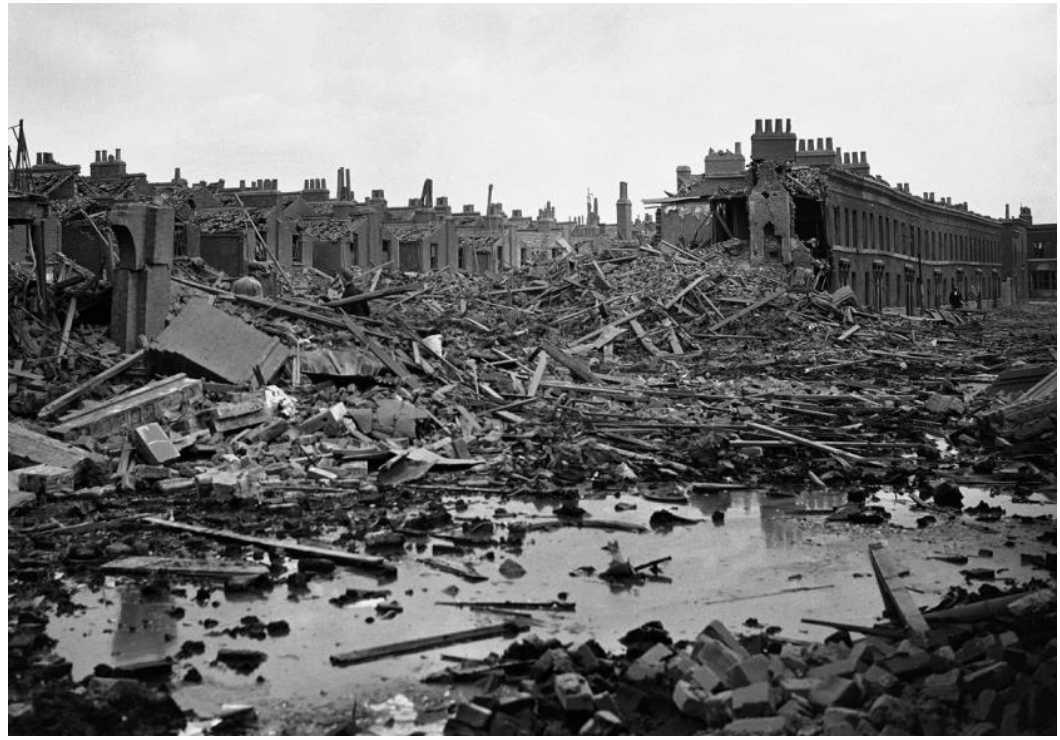

Figure 3 Irv, Blogs by. London docks area destroyed by bombing attack, January 1, 1970.

http://militaryhistoryofthe20thcentury.blogspot.com/2011/07/london-docks-area-destroyed-by-bombing.html.

Throughout this period, the reported crimes in Britain had "rose from 303,711 to 478,394 , an increase of 57 percent" [8]. Because of the difficult living conditions during that period, people did not hesitate to do things immorally, such as robbery and stealing. What's worse, almost one-third of those who had committed robbery or stealing were teenagers aged under seventeen [8]. That those teenagers thought the world owed them better lives[8] due to the tough lives explain these behaviors. We could see from it that there wasn't a stable and harmonious social environment, even for children to establish correct concept of morality or grow up positively. It reflected the adverse living condition and social atmosphere that British citizens had suffered from.

\section{CONCLUSION}

As the severe consequence of winning World War II brought Britain and its citizens the declining economy, the shortage of daily necessities, and the exacerbating of social morality to name a few, it was safe to conclude that not every country which had won a war could get good influence and results and we should consider deeply when facing particular wars. However, in the $21^{\text {st }}$ century, a peaceful era, countries should try their best to communicate gently with each other, avoid starting wars, and build a harmonious world. After all, the wars could bring human egregious effects.

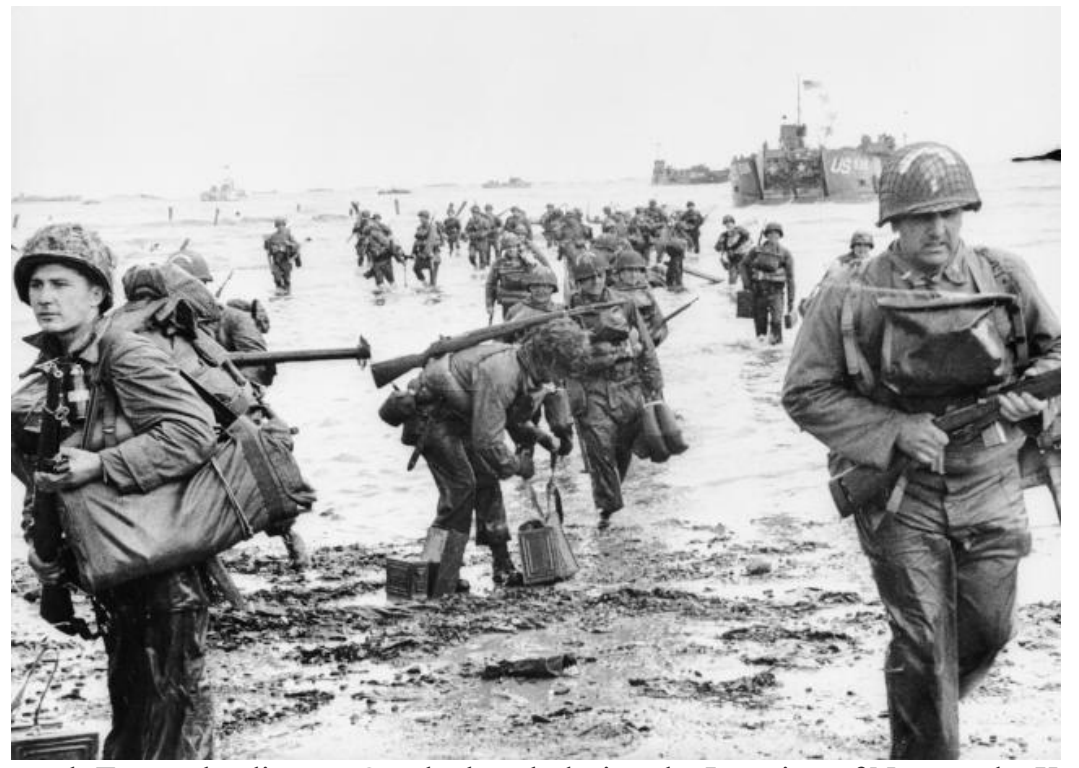

Figure 4 US Assault Troops landing on Omaha beach during the Invasion of Normandy. Keystone/Hulton Archive/Getty Images Rosenberg, Jennifer. "20 Major Battles of World War II." ThoughtCo, Aug. 27, 2020, thoughtco.com/major-battles-of-world-war-ii-1779996. 


\section{REFERENCES}

[1] "Age of Austerity - Life after War - WJEC - GCSE History Revision - WJEC - BBC Bitesize." BBC News. BBC. Accessed March 26, 2021. https://www.bbc.co.uk/bitesize/guides/zgmf2nb/rev ision $/ 1$.

[2] "Austerity Comes Under Cross-Fire", Ferdinand Tuohy,Volume 195(11December 1948): 338

[3] Basketter, Simon. "Austerity Britain, 1945-1951." Socialist Review. David Kynaston, January 1, 1993. http://socialistreview.org.uk/315/austerity-britain1945-1951.

[4] Dean, Mack. "World War 2 Quotes." World War 2 Facts. Mack Dean, March 4, 2021. http://www.worldwar2facts.org/world-war-2quotes.html.

[5] "First Austerity Christmas," The Field, Volume 186 (22 December 1945): 650.

[6] "What Was Life like after ww2." World war 2 stuff. Historymembersww2. Accessed April 8, 2021. http://historyremembersww2.weebly.com/whatwas-life-like-after-ww2.html.

[7] "Why Rationing and Shortagescontinued in Britain after WW2." Rationing and shortages continue in Britain after WW2. Accessed March 26, 2021. https://www.1900s.org.uk/1940s50s-rationingshortages-post-war.htm.

[8] "10 Facts about Crime on the Home Front in the Second World War." HistoryExtra. BBC History, November 26, 2020. https://www.historyextra.com/period/secondworld-war/10-facts-about-crime-on-the-homefront-in-the-second-world-war/. 